\title{
EUROPEAN CYCLE TOURISM: A TOOL FOR SUSTAINABLE REGIONAL RURAL DEVELOPMENT
}

\author{
Pieter Piket $^{1 *}$,Eke Eijgelaar ${ }^{1}$ \& Paul Peeters ${ }^{1}$ \\ ${ }^{I}$ NHTV Breda University of Applied Sciences, Centre for Sustainable Tourism and Transport, Netherlands \\ e-mails: piket.p@nhtv.nl,eijgelaar.e@nhtv.nl,and peeters.p@nhtv.nl \\ *corresponding author
}

\begin{abstract}
We present an economic impacts model based on direct expenditures for European cycle routes, originally designed in 2009 as part of a study commissioned by the European Parliament. At its request, the study was updated in 2012, including a refined version of our model which takes some limitations of the former model into account. Our main findings are that cycle tourists' daily spending is comparable to that of other tourists, and that cycle tourism can contribute significantly in particular to rural economies that have not previously enjoyed mainstream tourism development. (European) cycle tourism thus proves to be useful as an (additional) tool for regional rural development. We arrived at a total estimated direct expenditures in Europe of almost $€ 44$ billion ( $€ 35$ billion from day trips and $€ 8.94$ billion from overnight trips). We applied the model to the routes of EuroVelo, the European cycle route network which is currently being developed, showing their considerable economic potential of over $€ 7$ billion in direct expenditures. Furthermore, cycle tourism has a far lower negative impact on the environment (in terms of carbon dioxide emissions) than other forms of tourism. Cycle tourism is therefore a good example of a low carbon tourism product which could be developed as a major slow travel opportunity across (rural) Europe.
\end{abstract}

Key words: cycle tourism, tourism transport, economic impacts, sustainable tourism development, regional rural development

\section{Introduction}

In 2009, we co-authored a research report on European cycle tourism for the European Parliament (Lumsdon et al. 2009), the findings of which were summarised and updated in Eijgelaar et al. 2011a and 2011b. At the request of the European Parliament we updated the report in 2012 (Weston et al. 2012). Among others, both reports provided estimations as to the volume and (monetary) value of the cycle tourism market across Europe and sought to evaluate the potential for further development.

The economic significance of several existing European cycle routes was estimated using a newly developed (Lumsdon et al. 2009) and further refined (Weston et al. 2012) Cycle Route Demand Forecast Model (CRDFM). We also looked at the potential economic benefits of envisaged European cycle route networks.

This paper starts by summarising the most important updated findings with regard to the European cycle tourism market. The refined model is then presented, including suggestions for further improvements. The Eurovelo European cycle route network is used as case study. The sustainability of cycle tourism is then briefly touched upon before the conclusion, in which the usefulness of (European) cycle tourism as a tool for regional rural development is assessed.

\section{Materials and methods}

\subsection{European cycle tourism market: Number of cycle holidays and day trips}

Both EP studies distinguish between cycle holidays and cycle day trips. In the absence of data on the demand for cycle tourism across countries, we reviewed reports from countries where studies have been undertaken. An analysis of this material provides an overview of the demand for cycle tourism across Europe. This generalised approach is possible because cycle tourists have very similar characteristics across most countries. However, we did apply differences which affect the propensity to cycle in everyday life and to choose cycling as part of a holiday.

Within the context of the overall outbound market, cycle tourism remains small-scale in Europe, the focus lying with domestic markets. The marginal growth of cycle tourism, both in terms of provision and market demand, is uneven across Europe. In countries such as Austria and France cycle tourism is still growing, while in other countries, such as Denmark, Germany, Switzerland and The Netherlands it may have reached saturation. 
Lumsdon et al. (2009) and Weston et al. 2012 did not present a forecast of the demand for European cycle tourism based on data which is readily available in every country, but rather a less accurate estimate based on incomplete and scattered data. Our model uses fractions of existing tourism flows within Europe (EU27 plus Norway and Switzerland). Tourism departure data has been related to population size per country (Eurostat 2008) assuming a certain number of trips per capita for every country, as well as to adapted domestic and international tourism flows taken from earlier work by Peeters et al. (2004).

In the 2009 EP study (Lumsdon et al. 2009), it was estimated that there were 2.795 billion cycle tourism trips in Europe per annum. One of the key points of criticism of these estimates was that they sometimes differed considerably from the figures in national studies (Krieger and Baum 2011). For the 2012 update, the method and estimates for European cycle tourism have been revised.

As with the 2009 study, countries were divided into three bands of high, medium and low demand. In order to overcome some of the perceived deficiencies of the 2009 estimates, two changes have been made. Firstly, three new bands were added to the levels of demand, giving six in total, ranging from low to very high. This increases the sensitivity to national variations in demand. The second improvement was to link the banding of countries to the general use of bicycles as a mode of transport for each country (The Gallup Organisation 2011), rather than being based solely on expert opinion (Lumsdon et al 2009). The results are shown in Table 1.

Factors were generated from collected cycle tourism data and allocated to each of these bands. These were then applied to overall tourism demand to generate an estimated demand for cycle tourism in each country. This resulted in 2.295 billion cycle tourism trips ( 2.274 billion day trips and 20.36 million overnight trips) per annum in Europe (EU27 plus Norway and Switzerland).

\subsection{European cycle tourism market: Direct expenditures}

One important aspect of cycle route development is the way in which direct spending in local economies can generate businesses and create and/or maintain jobs. This is particularly important in mostly rural areas which are not tourist 'honey pot' sites and would not be able to attract visitor spending otherwise.

We needed data on average individual tourist expenditures to estimate the economic impacts of cycle tourism. Since almost all the available research is based on tourist questionnaires we needed to limit our calculations to direct tourist expenditures. Additional indirect and induced effects are not taken into account.

The Swiss Veloland cycle network has been monitored extensively from the projects' inception, and its use has been high since its early stages of development. The total number of cyclists per annum was 3.4 million in 1999 and rose to 5 million in 2009 (Utiger and Richardson 2000; Utiger and Rikus 2010). After a temporary decline to 4.4 million in 2010, the total volume returned to 5 million in 2011 (Utiger and Rikus 2012). Total expenditures in 2011 were estimated at $€ 118$ million. On average, overnight holiday cyclists (staying more than 2 nights) spend $€ 71$ per day, of which $€ 28$ is on accommodation, and $€ 25$ on food and beverage (Ickert et al. 2005; Utiger and Ickert 2005).

A review of the available data on levels of expenditure across a number of other regional and national studies in Europe further illustrates this difference between cycle tourists and day cycle excursionists. We used those studies providing cyclist volumes, average length of stay and daily spending to calculate a trip-excursion weighted average. It should be stressed that these studies are, to a large extent, incomparable due to the different methods and samples used. Nevertheless, the similarities of nearly all overnight (between $€ 50$ and $€ 70$

Table 1. Cycle tourism demand bands. Source: Weston et al. 2012: p.35

\begin{tabular}{|c|c|c|c|c|c|c|}
\hline Demand band & Low & Low-Medium & Medium & $\begin{array}{l}\text { Medium- } \\
\text { High }\end{array}$ & High & Very high \\
\hline $\begin{array}{l}\text { Share of population using cycling } \\
\text { as main mode of transport (The } \\
\text { Gallup Organisation, 2011) }\end{array}$ & $\leq 2 \%$ & $>2-5 \%$ & $>5-<8 \%$ & $8-12 \%$ & $12-20 \%$ & $>20 \%$ \\
\hline $\begin{array}{l}\text { Expert estimate share of cycle } \\
\text { holidays as } \% \text { of all holidays }\end{array}$ & $0.5 \%$ & $1 \%$ & $1.5 \%$ & $2 \%$ & $3 \%$ & $3.7 \%$ \\
\hline $\begin{array}{l}\text { Countries attributed to demand } \\
\text { band }\end{array}$ & $\begin{array}{l}\text { Turkey**/*** } \\
\text { Bulgaria } \\
\text { Luxembourg } \\
\text { Portugal } \\
\text { Malta** } \\
\text { Cyprus } \\
\text { Spain }\end{array}$ & $\begin{array}{l}\text { Romania } \\
\text { Lithuania } \\
\text { Serbia**/*** } \\
\text { Norway*** } \\
\text { Croatia**/*** } \\
\text { Macedonia**/*** } \\
\text { Italy } \\
\text { Estonia } \\
\text { Ireland } \\
\text { Greece } \\
\text { UK }\end{array}$ & $\begin{array}{l}\text { Latvia } \\
\text { Czech R. } \\
\text { Slovenia } \\
\text { France* }\end{array}$ & $\begin{array}{l}\text { Slovakia } \\
\text { Poland }\end{array}$ & $\begin{array}{l}\text { Hungary } \\
\text { Denmark } \\
\text { Sweden } \\
\text { Belgium } \\
\text { Germany } \\
\text { Finland } \\
\text { Austria* } \\
\text { Switzerland*/*** }\end{array}$ & $\begin{array}{l}\text { Nether- } \\
\text { lands }\end{array}$ \\
\hline
\end{tabular}

* Austria, Switzerland and France have been moved up one demand band in order to compensate for a lower daily usage share of cycling with demonstrated high shares of incoming cycle tourists. $* *$ These countries could not be included in the estimate for Europe due to missing background data. ***These countries do not feature in the modal split data of The Gallup Organisation (2011). They have been attributed a 'cycling as main transport mode' share based on other, similar data on bicycle usage and the shares of neighbouring countries. 
per day) and day excursion spending figures (between $€ 10$ and $€ 20)$ are evident. Evidence from one cycle route (Elbe SaxonyAnhalt) points towards a relatively constant daily spending level over the years (2004-2011; Peters 2012). Table 2 gives a detailed look at the resulting average direct expenditures per type and activity.

Table 2. Average direct expenditures per type and per activity Source: Weston et al. 2012

\begin{tabular}{|l|l|}
\hline Expenditures per day and per trip & $€ 57.08$ per day \\
overnight cycle tourists incl. & $€ 439$ per trip (average length of stay: \\
accommodation & 7.7 days) \\
\hline Distribution over different activities & $€ 23$ Accommodation $(40 \%)$ \\
of overnight cycle tourists & $€ 17$ Food and Beverage $(\mathrm{F} \& \mathrm{~B})(30 \%)$ \\
& $€ 17$ Other $(30 \%)$ \\
\hline Expenditures day excursion cyclists & $€ 15.39$ of which $60-75 \%$ on $\mathrm{F} \& \mathrm{~B}$ \\
\hline
\end{tabular}

Together with the estimated annual 2.295 billion cycle tourism trips (2.274 billion day trips and 20.36 million overnight trips) in Europe (EU27 plus Norway and Switzerland), we arrived at estimated direct cycle expenditures in Europe of almost $€ 44$ billion ( $€ 35$ billion from day trips and $€ 8.94$ billion from overnight trips).

\subsection{The Cycle Route Demand Forecast Model (CRDFM)}

For the 2009 EP report by Lumsdon et al. (2009), the Cycle Route Demand Forecast Model (CRDFM) was designed to generate estimates per year of the number of cycle holiday trips, day trips and direct expenditures of these visits on a particular cycle route, per region and in total. It is geographically based and the input required is the code of each NUTS 3 region $^{1}$ the cycle route passes through and the distance of the route within these regions.

From the publicly available data sources on cycle tourism in Europe as discussed and analysed in Lumsdon et al. (2009), we developed an approach for modelling demand and expenditures. The model was updated in Weston et al. (2012) from its original 2009 version including new study results. National figures on cycling as a main mode of transport (The Gallup Organisation 2011; See also Table1) were added and multiplied with population density as an extra determining factor in order to arrive at better estimates of day trip volumes.

For cycle holidays or overnight trips:

- $\quad$ trips $/ \mathrm{km}=\mathrm{f}\left(\right.$ tourism beds $\left./ \mathrm{km}^{2}\right)$ and direct expenditures $=\mathrm{f}(€$ per trip $)$

Cycle day trips:

- $\quad$ trips $/ \mathrm{km}\left(\right.$ Lumdson et al 2009) $=\mathrm{f}\left(\right.$ population $\left./ \mathrm{km}^{2}\right)$

- $\quad$ trips $/ \mathrm{km}$ (Weston et al 2012) = $\mathrm{f}(\%$ population with bicycle as main mode $\mathrm{x}$ population $/ \mathrm{km}^{2}$ )

- $\quad$ direct expenditures $=\mathrm{f}(€$ per trip $)$

${ }^{1}$ NUTS (Nomenclature of territorial units for statistics) regions are defined by EuroStat. NUTS 3 is the most detailed level for socio-economic analyses, as small regions for specific diagnoses (see http://epp.eurostat.ec.europa.eu/ portal/page/portal/nuts_nomenclature/introduction).
These relations turned out to be the most significant from a multitude of variables such as GDP/ $/ \mathrm{km}^{2}$, population $/ \mathrm{km}^{2}$, daily modal split, nights $/ \mathrm{km}^{2}$ and beds/route-km.

For holidays, the number of trips per route kilometre per year is 30.91 times the number of beds (all accommodation types) per square kilometre of the NUTS 3 region through which the route passes or within which the network is situated.

For day excursions, the number of trips per kilometre per year is 24.9 times the number of people per square kilometre of the NUTS 3 region multiplied by the (national) share of the population that uses cycling as their main mode of transport in the area through which the route runs or within which the network lies at the NUTS 3 level.

Despite the refinements there are still several limitations. It has higher relevance for rural areas and for those Western European countries that provided input for the model (particularly Germany, Switzerland, Austria, and the Netherlands). It can be assumed that the average direct cycle expenditures in (most of) the Central and Eastern European countries will be (much) lower due to (much) lower costs and consumer prices for accommodation, F\&B, and so on. Møller Munch (2009) showed that daily spending by cycle tourists can also vary per country of origin. The availability and density of various products for cycle tourists in a region (gastronomy, local products, shopping, and so on) also determine the amounts they (can/will) spend to a large extent (Mercat 2009; Quack and Hallerbach 2012). The use of direct expenditures fails to take into account indirect and induced economic effects and ignores expenditures leaking out of the local/regional economy. In reality, trip numbers do not suddenly change drastically at district borders. Therefore, the overall figures are likely to be more realistic than those at the NUTS 3 level. To conclude, the model also fails to differentiate between target markets and neglects the influence of marketing.

\section{Results and Discussion}

\subsection{Case Study: EuroVelo network}

The EuroVelo Trans-European Network comprises of fourteen long distance cycle routes covering a distance of $70,000 \mathrm{~km}$, of which approximately $45,000 \mathrm{~km}$ are in existence at the moment (ECF 2013). A completed EuroVelo network could potentially result in over $€ 7$ billion of direct expenditures: 14.5 million holidaymakers (111.65 million holiday cycle days) with total direct expenditures of $€ 6.38$ billion and 45.54 million day trips with $€ 0.70$ billion of direct expenditures.

As EuroVelo makes use of existing routes, this value only represents the direct expenditures, not the net additional economic impacts of the EuroVelo concept itself. These depend on the way the concept impacts on development in relation to missing stretches and by adding marketing value. There is also the consideration of the multiplier effect in each locality, bringing additional indirect and induced expenditure especially in places where local supply chains and local businesses are well developed and properly interlinked. 
It should be stressed once again that the projections given by the model are for 'good to ideal' circumstances with an adequate and regular supply of facilities such as cafés, restaurants, shops, and so on. If these are absent or intermittent, the average spending figures used cannot be reached. Two studies in France (Bourgogne Tourisme 2010 and Mercat 2009) for example noted that a large percentage of day excursionists spent hardly anything (the average daily direct expenditures for all day excursionists were $€ 0.24$ and $€ 1.00$ respectively). The share of those not spending was much higher than reported for Germany and Switzerland, apparently due to a low supply of 'spending facilities' (Bourgogne Tourisme 2010).

\subsection{Sustainability}

Particularly for the tourism sector, a broader sustainabilityoriented context is relevant, as this is one sector where $\mathrm{CO}_{2}$ emissions have been and are expected to rise steadily (Scott et al. 2010). Emissions are largely produced during origindestination transport and mostly caused by cars and aircraft. Overnight cycle tourists use the train far more often and the car and plane much less often than average tourists do. Also, their average return distances are shorter, resulting in considerably fewer emissions. Accommodation emissions are also lower as they stay less in hotels, this being the accommodation type with the highest emissions per guest night. German cycle tourists, for example, produce $66 \%$ fewer holiday emissions per trip than the average German holidaymaker (Lumsdon et al. 2009). The carbon footprint $\left(\mathrm{CO}_{2}\right.$ emissions) of domestic cycle holidays in the Netherlands is $35 \%$ smaller than average, which is considerable in regard to the short transport distances for both cyclists and average tourists (de Bruijn et al. 2011). As a result of these low emissions and average daily spending, the eco-efficiency (a measure for comparing expenditures with $\mathrm{CO}_{2}$ emissions) of cycle tourism is nearly always higher than for holidays made by cars or by aircraft.

\subsection{Conclusions: European cycle tourism, a tool for sustainable regional rural development}

For local and regional tourist boards and other planners of new cycle routes, we presented a model to allow estimates of demand and direct expenditures generated by (European) cycle routes. The model has been calibrated mainly on Western European cycle routes because of a lack of studies into other cycle tourism areas.

There are still a number of barriers to the development of sustainable European cycle tourism. Carrying a bicycle by rail is relatively inexpensive, but not always possible and in most cases not easy. Carrying a bicycle on an aeroplane is always possible, requires some mechanical changes and a cover, but is relatively expensive compared to rail. The solution here might be that rail increases the price of carriage and invests these extra revenues in making it more convenient to travel with a bicycle. Another barrier is the lack of quality of long distance routes and networks in many, mainly non-Western European, countries. Thirdly, in general terms, tour operators and other tourism providers show low involvement in the development of cycle tourism.

The evidence assessed in the EP studies and this paper indicates that cycle tourists bring major (additional) benefits to localities which do not currently enjoy mainstream tourism development. These results convinced the EP of the (monetary) value of cycle tourism. At the end of December 2012, the EP decided to incorporate cycling, tourism and the EuroVelo infrastructure into the approved TEN-T network with the future possibility of (additional) EU funding (ECF 2012). The development of routes is relatively low cost, re-using disused assets such as canal towpaths, old railway tracks, or shared road space on (high)ways where traffic levels are generally low. Finally, it has the advantage of being a sustainable, lowcarbon form of tourism which could be developed as a major slow travel opportunity across (rural) Europe.

\section{References}

Bourgogne Tourisme. Fréquentation et impact du Tour de Bourgogne à vélo. Dijon, France: Bourgogne Tourisme, 2010.

de Bruijn K, Dirven R, Eijgelaar E. and Peeters P. (2011): Travelling large in 2009: The carbon footprint of Dutch holidaymakers in 2009 and the development since 2002. Breda, The Netherlands: NHTV Breda University of Applied Sciences; NRIT Research; NBTC-NIPO Research.

ECF. 'Our Voice Was Heard' (2012): Cyclists' Movement Wins Support In Crucial EU Transport Infrastructure Vote. Online document at URL http://www.ecf.com/news/our-voice-was-heard-cyclistsmovement-wins-support-in-crucial-eu-transport-infrastructure-vote/ ECF . (2013): What is EuroVelo? Online documents at URL http:// www.eurovelo.org/home/what-is-eurovelo/ .

Eijgelaar E., Peeters P. and Piket P. (2011a): Have Bicycle, will travel. Cycling Mobility, 1(1): 48-51

Eijgelaar E., Peeters P. and Piket P. (2011): European Cycle Tourism: Tool for Sustainable Regional Rural Development? Research in Progress Paper. Second AGRIMBA-AVA Congress, 23 and 24 June Wageningen, The Netherlands, 2011b.

Eurostat (2008): Eurostat data navigation tree. Online documents at URL http://epp.eurostat.ec.europa.eu/.

Ickert L, Rommerskirchen S, Weyand E. and Veloland Schweiz (2005): Ergebnis-Band zur Gästebefragung. Zählung und Befragung 2004, Basel, Switzerland: ProgTrans AG.

Krieger C. and Baum C. (2011): Market Analysis Report on the Rhine Cycle Route. Kleve, Germany: Euregio Rhein-Waal.

Lumsdon L., Weston R., McGrath P., Davies N., Peeters P., Eijgelaar E., and Piket P. (2009): The European cycle route network EuroVelo: challenges and opportunities for sustainable tourism. Brussels, Belgium: European Parliament, Directorate General for Internal Policies, Policy Department B: Structural and Cohesion Policies, Transport and Tourism.

Mercat N. (2009): Spécial économie du vélo. Étude complète. Paris, France: ATOUT FRANCE.

Møller Munch D. (2009): Cykelturismens økonomiske betydning for Danmark 2008. Copenhagen, Denmark: Aktiv Danmark. 
Peeters PM., van Egmond T. and Visser N. (2004): European tourism, transport and environment. Final Version, Breda, The Netherlands: NHTV CSTT.

Peters U. (2012): Radfahrerstatistik Elberadweg 2001-2011. Magdeburg, Germany: Magdeburger Tourismusverband Elbe-Börde-Heide e.V.

Quack H-D, Hallerbach B. Fallbeispiel (2012): Wertschöpfung im Radtourismus am Beispiel von Rheinland-Pfalz. In: Dreyer A, Mühlnickel R, Miglbauer E, editors. Radtourismus: Entwicklungen, Potentiale, Perspektiven. Münich, Germany: Oldenbourg Verlag.

Scott D., Peeters P., and Gössling S. (2010): Can tourism deliver its "aspirational" greenhouse gas emission reduction targets? Journal of Sustainable Tourism, 18 (3): 393-408.

The Gallup Organisation (2011): Flash Eurobarometer 312 "Future of transport". Brussels, Belgium: European Commission.

Utiger M. and Ickert L. (2005): Zählung und Befragung 2004 Veloland Schweiz: Resultate der Erhebung des Veloverkehrs auf den nationalen Routen im Veloland Schweiz. Bern, Switzerland: Stiftung Veloland Schweiz.

Utiger M., Richardson AJ. and Veloland Schweiz (2000): Resultate der Zählungen und Befragungen 1999. Erhebung des Veloverkehrs auf den nationalen Routen im «Veloland Schweiz». Bern, Switzerland: Stiftung Veloland Schweiz.

Utiger M., Rikus S. and Veloland Schweiz (2009): Ergebnisse Velo-Zählungen. Kurzfassung. Bern, Switzerland: Stiftung SchweizMobil, 2010.

Utiger M., Rikus S. and Veloland Schweiz (2011): Ergebnisse VeloZählungen. Bern, Switzerland: Stiftung SchweizMobil, 2012.

Weston R., Davies N., Peeters P., Eijgelaar E., Lumsdon L., McGrath P. and Piket P. (2012): The European Cycle Route Network EuroVelo: Challenges and Opportunities for Sustainable Tourism. Update of the 2009 study. Brussels, Belgium: European Parliament, Directorate General for Internal Policies, Policy Department B: Structural and Cohesion Policies, Transport and Tourism. 
